\title{
THE PRESENT IS LOCAL, THE FUTURE IS GLOBAL? RECONCILING CURRENT AND FUTURE LIVELIHOOD STRATEGIES IN THE EDUCATION OF CONGOLESE REFUGEES IN UGANDA
}

\author{
Sarah Dryden-Peterson \\ Refugee Law Project, Uganda \\ Harvard Graduate School of Education
}

\section{INTRODUCTION}

Refugees often see education of their children as the principal way of ensuring a better future for their family. In this way, pursuing education is a forward-looking livelihood strategy for both children and their parents. Just as importantly, education often plays a role in creating stability in the daily lives of displaced children. The double priority of current and future livelihoods, however, are in tension for fourteen-year old Bakari ${ }^{1}$ who fled the Democratic Republic of Congo (DRC) in 2000 and has since lived and gone to school in Kyaka II refugee settlement in Uganda.

Two factors combine in the context in which Bakari and thousands of other children find themselves to create a tension between these priorities. First, Bakari's situation is not locally stable. Continued large influxes of refugees due to on-going conflict mean infrastructure and programs for refugees are constantly inadequate. Further, changing numbers mean changing relationships between refugees and host communities, especially as the demand on local resources such as schools and clinics increases. Second, refugees from Congo find themselves in a protracted situation; they have lived in exile for more than five years and have no immediate prospect of finding a durable, long-term solution (Crisp, 2003). While Bakari's present is certainly local to Uganda, his future is unclear. He says, "I would choose [to go home] to Congo, if there would be no war" (interview, 1 June 2004). The conditional nature of his statement underscores deep uncertainty about the future.

This uncertainty about where to focus one's energies - on the present or the future - is not the sole domain of a fourteen year-old child. It faces every actor in displacement situations, most particularly refugee communities, host communities, the United Nations High Commissioner for Refugees (UNHCR), and host governments. UNHCR envisions that there are three possible durable solutions, which would bring closure to a displacement experience, leading to certainty about the future. Bakari could return to his home country through "voluntary repatriation;" he could experience "local integration," settling permanently in his country of first asylum; or he could be "resettled" to a third country. Bakari's 
needs in order to ensure his current livelihood and his needs for each of the alternative durable solutions, however, are at odds. This disjuncture is critical: With increasing numbers of displaced people worldwide and the extended duration of many of the conflicts that cause the displacement, the need for reconciliation of current and future livelihoods in both policy and its implementation cannot be ignored.

Is it possible for Bakari to experience current stability and future prospects at the same time? Language of instruction in schools embodies the tension of this double priority and is thus a productive lens through which to examine this critical question. Indeed, language policy imperatives for current stability in a local context and for future prospects in an uncertain context are often in tension. Bakari grew up speaking Lihuku in his home, Kiswahili with his neighbors and in the market, learning French at school in Congo, being sent back two grades upon arrival in Uganda in order to learn English; and, of course, the language of his future is uncertain. Through an examination of the case of Bakari's school Bujubuli Primary School - and the issues of language that it faces, I aim to highlight the tension between current and future livelihoods, demonstrate why this tension is in critical need of attention, and present some strategies to address it that could be adopted by policy-makers as well as by implementing partners working with displaced communities in the field.

In examining the tension between current and future livelihoods, I first outline the language policies of UNHCR, the organization mandated with the provision of education for refugees, and set these policies in the context of larger academic debates about language of instruction in schools. Second, I explain the methodology I used to conduct this research. Third, I present a portrait of language at Bujubuli Primary School, focusing on the experiences of teachers, children, and families and the implications for their livelihoods. I conclude with an analysis of how to address the concerns of teachers, children, and families at Bujubuli Primary School and how to relate this context-specific investigation to the tension between current and future livelihoods in displacement situations worldwide.

\section{LANGUAGE OF INSTRUCTION: POLICY AND THEORY}

One of the first questions addressed when setting up education in emergency situations is: what will the language of instruction be? The standards for UNHCRfunded schools state specifically that the language of instruction in a displacement situation should be the "language used in the country of origin schools" (UNHCR, 2003a: 73). In this way, the language policy assumes the viability of and supports UNHCR's preferred durable solution: voluntary repatriation.

Recent work on the Minimum Standards for Education in Emergencies (MSEE) recognizes that implementation of this clear and straightforward language policy can be difficult. Current initiatives such as Convention Plus Targeted Development Assistance, which aims to foster greater collaboration between UNHCR and host governments in order to more efficiently use scarce resources, 
have resulted in the integration of services such as education (Crisp, 2003, 2004; Dryden-Peterson \& Hovil, 2004; Banki, 2004). In the case of integration in particular, "it is not uncommon for asylum countries to insist that refugee education programmes comply with their standards, including the use of their language and curricula" (INEE, 2004: 58). When refugees and nationals study together in the same schools, there is little possibility for instruction in the language of the country of origin. The language policy then supports a different durable solution: local integration.

Recognizing the conflict between these two resolutions to the dilemma of language of instruction, UNHCR advocates that education "face both ways," so that it respects the present situation of pupils in the country of asylum and their potential future in the country of origin. For Bakari, this imperative requires adequate instruction in both the English of Ugandan schools and the French of DRC schools. Nevertheless, UNHCR and the Interagency Network for Education in Emergencies (INEE) recognize that there is little likelihood that schools can face both ways equally. They thus suggest either the employment of refugee teachers who know the language and curriculum of the country of origin, with subject time given to learning the language of the host country; or integration within a local system of education with supplementary classes and activities in the language of the country of origin (UNHCR, 2003b; INEE, 2004).

This policy of "facing both ways" can be compared to policies of multilingualism in place in many parts of the world (see for example, Omoniyi, 2003; Dutcher, 2001; Baker, 1996; Bamgbose, 1991). Children are expected to complete primary school with academic proficiency in more than one language. In an increasingly globalized world, policymakers - as well as many parents - argue that this approach provides critical economic advantages for children: Literacy in more than one language will increase access to livelihoods. However, the liabilities of this approach are also numerous. Bamgbose argues that "[l]anguage is without a doubt the most important factor in the learning process, for the transfer of knowledge and skills is mediated through the spoken or written word" (1991). Yet decades of research on language of instruction have shown that in multilingual situations, language barriers often limit children's access to knowledge or skills. August and Hakuta, for example, demonstrate that children become more able readers if they acquire literacy in their first language and only then transfer those skills to a second language (1998). The most recent literature dismisses the idea that proficiency in a second language is best gained when it is the language of instruction as a misconception (Brock-Utne \& Holmarsdottir, 2004). Further, poor implementation can mask solid policy. For instance, in situations where teachers are poorly trained in the language of instruction, children often complete their educations without ability in that language or solid training in subject matters (Qorro, 2002; Baker, 1996; Bamgbose, 1991). Fafunwa argues that the imposition of colonial language further exacerbates this situation and claims a correlation between underdevelopment and the use of a colonial language as the official language of instruction (1990: 103). 
While UNHCR's policy of "facing both ways" attempts to reconcile the dual priority of current stability and future prospects, it assumes the viability of multilingual approaches and instruction in languages foreign to many children, often colonial languages. The challenges posed to this approach by the developmental and educational literature on language learning further complicates the question of current stability and future prospects and provides critical dimensions on which UNHCR policy and practice in schools must be evaluated.

\section{METHODOLOGY ${ }^{2}$}

\section{Site}

Kyaka II Refugee Settlement is located in Kyenjojo District in Western Uganda on 81 square kilometres of land (interview, Bomera, 2003) approximately 70 kilometres by road from the town of Mubende. The Kyaka area first hosted refugees in the 1950s following political turmoil in Rwanda that led to the flight of thousands of Tutsis into Uganda (Barongo, 1998: 118-122). Kyaka II was created as a refugee settlement to host these refugees in 1959, and many of them stayed until 1994 when they returned to Rwanda. Since 1994, Kyaka II has hosted primarily Congolese refugees and Rwandese of Hutu origin. The Office of the Prime Minister (OPM) was the implementing partner for UNHCR in Kyaka II until mid-2003, responsible for the implementation of all health and sanitation, education, agriculture, and micro-finance programs in the settlement. Responsibility for these activities was handed over to the Uganda Red Cross Society (URCS) in 2003, and to GTZ, the German Cooperation, in 2005.

There are three primary schools in Kyaka II refugee settlement. I choose Bujubuli Primary School as a case study school because, at the time of initial selection, it served an approximately equal number of refugee and national pupils. Under initiatives such as the Self-Reliance Strategy in Uganda (OPM/UNHCR, 1999) and UNHCR's more recent Targeted Development Assistance approach (UNHCR, 2004; UNHCR 2005), which seek possibilities of local integration, schools with balanced populations of refugee and national pupils are a policy goal; a case study of a school serving this type of population was thus policy relevant.

At the end of December 2002, there were 1,242 refugees living in Kyaka II: by the end of 2003, the population had almost quintupled, to 6,175 ; by mid2005, the population of the settlement was over 12,000. Bujubuli Primary School also grew rapidly over this time, accommodating the influx of refugees. At the outset of 2003, there were 347 pupils; by the middle of 2004, there were 911 pupils; and in mid-2005, there were 1,272 pupils. The population of the whole settlement in 2002 was equal to the population of one primary school in 2005 (see Table 1). Through the fluctuations in population and the changing ratio of refugee and national pupils, the language of instruction at Bujubuli Primary School remained English. 
Table 1. Enrollment at Bujubuli Primary School, by year and country of origin

\begin{tabular}{|c|c|c|c|c|c|c|c|c|}
\hline 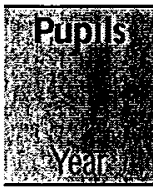 & 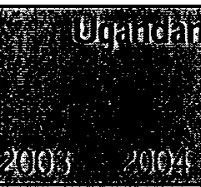 & 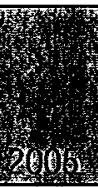 & 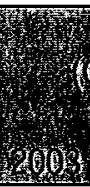 & $x$ & 2006 & & (xt & 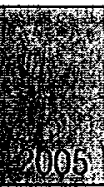 \\
\hline P1 & $48-63$ & 128 & 70 & 273 & 351 & 118 & 356 & 479 \\
\hline $\mathrm{P} 2$ & $236 \times 57$ & 86 & 49 & 125 & 148 & 72 & 182 & 234 \\
\hline P3 & $37, \quad 448$ & 76 & 28 & 115 & 123 & 65 & 158 & 199 \\
\hline P4 & $20, \times 37$ & 66 & 26 & 62 & 81 & 46 & 93 & 147 \\
\hline P5 & $14 \times<>20$ & 65 & 6 & 37 & 38 & 20 & 57 & 103 \\
\hline P6 & $5,>>14$ & 47 & 10 & 15 & 27 & 15 & 29 & 74 \\
\hline P7 & $8, y 6$ & 11 & 3 & 30 & 24 & 11 & 36 & 35 \\
\hline Total & $156 \quad 254$ & 479 & 192 & 657 & 792 & 347 & 911 & 1271 \\
\hline
\end{tabular}

Source: Bujubuli Primary School records, collected March 2003, July 2004, and June 2005

\section{Data collection}

I used multiple methods to collect data, each of which was employed in each year of the three-year longitudinal study. First, I interviewed key informants, including refugee and national community leaders, district-level officials, and educational officials. Second, I conducted school-based research that included interviews with pupils and teachers, classroom observations, and participant observation. I interviewed a total of eighteen children - eight refugees and ten nationals - at Bujubuli at yearly intervals; they also participated in 'check-in' exercises every four months. I selected participants at random from among pupils in the Primary 4 (P4) and Primary 5 (P5) classes, and I followed these participants over three years, whether or not they persisted in school. I was unable to interview one out of the eighteen children in the third year of the study as she had run away from her family to get married. I interviewed all of the teachers who taught study participant pupils in any given year, as well as the head teacher and deputy head teachers. I observed at least five lessons by the eight teachers in each year of the study, arriving unannounced at a given class after gaining their permission to conduct such observations. In addition to classroom-based observation, I conducted two weeks of sustained participant observation at Bujubuli Primary School in each year of the study interspersed with three-days of participant observation every four months.

Finally, I conducted a cross-sectional household survey of each participant pupil, both refugee and national. While the sampling of households for this study was not random, the selection of students for the study was, as is appropriate to analysis conducted at the school-level and not the community-or populationlevel. This survey, which drew significantly on the Demographic and Heath Survey (DHS) Uganda (USAID \& ORC Macro, 2005), developed by USAID and tested and administered by the Uganda Bureau of Statistics (UBOS), provided quantitative data on economic well-being and educational opportunity for refugees and nationals. 


\section{Analysis}

As I did classroom observations and interviews with teachers, pupils, and their families, and as I conducted household surveys and community leader interviews, the theme of language quickly became apparent. I thus began to listen for a story about language. I listened for how teachers, children, and parents perceived language and its relationship to present and future education and work. All interviews were transcribed verbatim, and I coded them, along with fieldnotes and classroom observations, using both emic and etic codes in the category of language.

In weaving together the story of language from the perspectives of three central actors - teachers, children, and families - my aim is to present experiences of language of instruction in a refugee settlement in southwestern Uganda. I do so through mini-portraits (Lawrence-Lightfoot \& Davis, 1997) that seek to address the central research question: How might schools promote both current and future livelihoods?

\section{A PORTRAIT OF LANGUAGE: BUJUBULI PRIMARY SCHOOL}

The motto of Bujubuli Primary School is "To learn for a better future." This mandate for learning applies to both the refugees and nationals who have populated the school since it opened as a Government of Uganda school in 1984. Two flags fly in the central compound of the school, perched on a hill overlooking the settlement: the Ugandan national flag and the flag of the Batoro people. At afternoon parades, the children sing the Ugandan anthem, the Ugandan school anthem, and the anthem of the Toro Kingdom. Each one of them, refugee and national, sing - in the words of the school anthem - that they are "young women and men of Uganda... uniting for a better Uganda." The teachers and pupils speak many languages, among them Rutoro, Runyankole, Alur/Acholi, Hema, Lihuku, Lendu/Gegere, Lugbara/Aluru, Kiswahili, English, and French. According to Ugandan policy, which applies to this Government of Uganda school, the language of instruction should be the local language, in this case Rutoro, until the end of Primary 3 and English thereafter (NCDC, 1999; NCDC, 2000). The experience of language at this school, however, differs for different stakeholders, as will become apparent through the mini-portraits presented below.

\section{Teachers}

In Primary 4 English class at Bujubuli Primary School - which took place in a makeshift classroom under a large mango tree - Teacher Innocent tried to explain the idea of 'cousin.' He only knew the word in English and in his native Runyankole. He asked a pupil who spoke Rutoro to translate from Runyankole to Rutoro, for the national pupils whose families came from the area around Kyaka, and also to Kinyarwanda, for the refugees from Rwanda. He then asked the refugees from Rwanda to translate to Kiswahili for the refugees from Congo. "I want everyone to understand," he explained. This long and complicated process of translation was for one word (classroom observation, 24 March 2003). ${ }^{3}$ 
When asked to describe the school, Teacher Wilson, the Head Teacher, began by telling me that Bujubuli had pupils from different nations who spoke many languages. From a pedagogical point of view, he said, language was the defining factor of the school. In planning each lesson, in teaching each class, in each interaction with pupils and their parents, teachers needed to consider the issue of language. Some teachers appreciated this challenge. Teacher Patrick, for example, described a decision to teach at Bujubuli Primary School based on his desire to learn French and Kiswahili; "I want to learn languages," he said, ". . so I can have that [economic] advantage or one day I can be a refugee in a country that uses that language." Other teachers saw language as a problem at the school. Teacher Lawrence said, "On a small scale, there is a problem with language more especially with refugees from Congo. The rate at which they are picking [up] English, even in upper classes is low because in their country they are used to French. That is a problem which I think can be wiped out with time."

All of the Ugandan teachers at the school expressed this confidence in the ability of refugee pupils to accommodate to the English language, over time. They outlined two strategies that they had adopted to address the issue. First, the Head Teacher explained that children were placed in a lower level of class than that which they had achieved in Congo in order to "begin this simple English." Bakunda Félicien, himself a refugee from Rwanda and the Uganda Red Cross and then GTZ employee in charge of overseeing all education programs, believed that this repetition of classes is simply the "extra effort" pupils need to make to succeed in a new system (interview, Bakunda, 2004). Second, teachers used the local language, Rutoro, in their teaching, which they believed, falsely, that all of the refugees from Congo could understand (interview, Bakunda, 2004; informal conversation with four other Ugandan teachers).

The two refugee teachers from Congo understood the situation differently. On my first day at Bujubuli in 2003, I left school and walked home with Teacher David. We made casual conversation for the first few minutes, and then he turned to me and, almost uncontrollably, shared the burden that he carried: "Our pupils have a problem. It is a problem of language. They are not able to learn in their own languages" (informal conversation, 24 March 2003). In particular, he worried about what would happen when the refugees went home. "English is not used at all in Congo," he explained. His children, he is sure, would be pushed back a class, maybe more, if they returned to Congo; they might not be able to make use of their education. He has experienced that language barrier in Uganda; though he had finished high school in DRC, he was forced to go back to high school in Uganda in order to learn English.

Teacher Samuel, from eastern Congo, previously taught English to adults newly arrived to Kyaka II settlement and then began to teach the largest class of Primary 1 ; in 2004, that class was over 150 pupils, 90 percent of whom were from Congo. Even though he spent long days working to give his pupils a foundation in English, his disillusionment with this system was palpable:

And now, for what concerns the school: It is populated, for the most part, by children who come from Congo who speak only French, Kiswahili, and 
Kinyarwanda. Unfortunately, the teachers who are available to them speak only English and Rutoro. It is very difficult in almost all the classes for the teachers to communicate with the children. If the teacher tries to explain something in the local language, if he only explains in Rutoro, that is also a foreign language for our children. You see the problem of this school.... My instinct is that, truly, this is a waste of time for the children coming from the outside because they do not understand the teachers. It is as if they are still in the forest of their own country. Because the child, at the end of the school day, will still not know what he did in class, as long as the question language is not addressed.

For both the present and the future, the implementation of language policies Bujubuli Primary School was failing Teacher Samuel's refugee pupils. Despite confidence in the ability of refugee pupils to learn English, the Head Teacher of Bujubuli agreed. He revealed to me that there was a gap in performance between refugee and national pupils. "I believe," he said, "that the cause is language" (informal conversation, 28 June 2004).

\section{Children}

Rakiya, one of Bakari's classmates, responded to my question of what she would most like me to know about her school as follows: "There is nothing except that we are looking for teachers who are capable of expressing themselves in our languages, French and Kiswahili" (interview, 3 July 2004). Despite an upbringing that discourages criticism of adults, the refugee children of Bujubuli had disagreements with the way their education system worked; they were not hidden far beneath the surface. Fifteen year-old Kanyangi, explained: "we don't study very well at school. The teachers know well that we come from another country, but they don't even worry themselves about explaining to us in ways we understand, us who don't yet understand English or Rutoro" (interview, 3 July 2004). Bakari experienced school the same way: "here we have very few lessons each day and in languages that I have not mastered. However in Congo, we had more lessons and in languages that I understood. The teacher here explains little, even though he knows that we do not understand the language" (interview, 1 July 2004).

The eight refugee children from Bujubuli Primary School who were part of the three-year longitudinal study spoke five different languages at home: Alur/Acholi, Hema, Lihuku, Lendu/Gegere, and Lugbara/Aluru. Three of these languages are Nilo-Saharan languages, with little or no similarities to the local Rutoro language; two of the languages - Hema and Lihuku - are Bantu languages, thus sharing origins with the local language of the Kyaka region. The Settlement Commandant made the argument that "for the elementary section, the teachers sometimes use the local language/dialect which is similar to the Hema language of DRC" (letter dated 11 August 2004). While it is true that the Hema language and Rutoro are almost identical languages, only one of the children in this study spoke Hema. The rest of them did not understand Rutoro, as their teachers believed them to do. All of them spoke Kiswahili to each other and were coming from a Francophone educational system. 
Specifically troubling for refugee children at Bujubuli was the feeling that they were "losing" their education. I spent one afternoon sports time talking with several refugee children who arrived from Congo in June and August 2003. "We are suffering because of the language," Serge explained. While these children had been in troisième secondaire [the third year of secondary school] in their homes in Bunia, eastern DRC, they were pushed back five and six years to Primary 5 and Primary 6 in Uganda (informal conversation, 29 June 2004). "English is very difficult," they repeated to me. But, almost universally; refugee children stated that they wished to go to school in order to learn English, a language they believed would be important to both their present in Uganda and their future, which they could only imagine in the abstract. Rather than immersion in the science and history curriculum of Uganda, years below their grade level, they wondered why they could not formally be taught this difficult language.

\section{Families}

In front of the main trading center in Kyaka II settlement, I met a woman from Congo who spoke fluent French. Her four children studied at Bujubuli Primary School. "They [the teachers] speak kiToro [Rutoro] and my children do not understand at all," she said to me, pleadingly (informal conversation, 26 March 2003). Anjelani's father expressed the same confusion about language in the school. When I arrived at Anjelani's home, the compound was perfectly swept. The home was more established than some in the area; the main house was made of sticks and mud. We sat inside on three chairs and at a table. There were banana plants planted around the compound, the sign of establishment. Anjelani's father made it clear that there was one reason he wanted to talk with me. He knew that I was interested in education, and he wanted me to know that language was the central barrier to his daughter's success. He explained that Anjelani was in première secondaire [the first year of secondary school] in DRC and then went back four years to Primary 3 when they arrived in Kyaka II. She was now in Primary 6 and just continuing "like that" (interview, 3 July 2004). He seemed devastated, but resigned to this delay.

Refugee families also expressed concern about language at Bujubuli Primary School in the way that it affected their own participation in their children's education. Kenyangi's father said explicitly: I do not understand what my children are learning at school because it is in "an English that I do not understand" (interview, 3 July 2004). Bakari's mother remarked on how little she saw Bakari learning; further, she felt powerless to do anything about it. It was so hard to know what was going on in school and to learn about how her child was doing, she explained, because she did not speak the language. She said, "I see every day that my son's teacher has written 'good, very good, excellent' in his exercise book. But I ask my child to read me what is in his book and he cannot do it. Alas, where does this work come from and why are there such remarks in the book when the pupil does not even know what he is doing?" (interview, 1 July 2004).

Families described a direct connection between this disappointment in their children's present educational opportunities and their thoughts about the future. 
"Education is the key to the future," I heard repeated again and again in interviews. But this optimistic sentiment was often followed closely by questions about whether the specific education available to children at Bujubuli Primary School could be a productive key. Bakari's mother exclaimed: "When our children arrive at school here, they understand almost nothing and we do not know what our children will do when they return to Congo" (interview, 1 July 2004). She was devastated that Bakari did not understand the work he was doing in English and that he would not know what he was doing in French should he return to Congo. According to families, education at Bujubuli for refugees may not be facing both ways; it may not be facing either the present or the future at all.

\section{CONCLUSIONS: CURRENT STABILITY, FUTURE PROSPECTS}

Refugees see the education of their children as a way to prevent the recurrence of violence and to create economic opportunities that allow them to become selfreliant. UNHCR perceives for education this same role. Education in contexts of displacement indeed emerges from a double priority: current stability and future prospects. As I have attempted to demonstrate through the case of Bujubuli Primary School, language of instruction is a central issue in this dual imperative; it can be both barrier and opportunity for refugees with a local present and an uncertain future.

In the minds of teachers, children, and families, the possibilities of an education that "faces both ways," toward a country of origin and a country of asylum, is appealing. Indeed, the future prospects of an educated child who fluently speaks both the English of Uganda and the French of Congo are dreams in a refugee settlement like Kyaka II. School-based practice vis-à-vis language, however, reveals the on-the-ground limitations of implementing such ideal policies. In attempting to foster current stability through the UNHCR priority of local integration in Uganda, the language of instruction is the language of the host school. The resulting situation is that the refugee pupils, who are the vast majority of children in the school, do not understand their national teachers, repeat classes in an attempt to learn English, and leave school unable to function in either their new language of instruction or in their old one.

Given this situation, what of the possibility that schools might promote current and future livelihoods at the same time? The experiences of teachers, children, and families at Bujubuli Primary School suggest a fundamental rethinking of the role of language in primary education in situations of displacement. Policies that would work for current stability and future prospects are certainly appealing. However, an attempted balance between the two - especially given the constraints of implementation - leaves children stranded, hanging between two systems, without the possibility of being educated in any language. Two central, and related, recommendations thus emerge from this analysis. They are directed to policymakers from UNHCR and host governments and to practitioners, the teachers and community members in situations of displacement. 
First, language, as a critical point of access to education, needs to be recognized as a potential stabilizing force in the lives of refugee children. A confusion of languages, such as that created by the policy of "facing both ways," adds to the chaos of displacement. I recommend that clear decisions be made about one language of instruction in order to promote current stability no matter the future durable solution. In the situation in which Bujubuli Primary School finds itself, where national and refugee pupils are integrated in the same schools, that language must of political and logistical necessity be the language of the host country. A different situation, however, would require a different decision.

Second, ability in a language must not be interpreted as synonymous with a child's level of education. Demoting pupils to lower classes serves to disrupt children's peer groups and to negatively affect their self-esteem; combined with the general uncertainty created by displacement, the effects of these actions can be devastating for children. Rather than demote them to classes below their academic and social level, teachers can recognize the content knowledge and skill level of older children and equip them with tools of language. Intensive language classes for new arrivals could prevent the "losing of education" that pupils at Bujubuli Primary School described and help to create the educational stability and the concrete future livelihood prospects that come with educational attainment.

Children in situations of displacement need current stability in order to even imagine the future. Thus, if a decision is made to face the country of origin, then children need to be immersed in their familiar language of instruction. If a decision is made to face the country of asylum, as in the case of Uganda, then children need intensive language resources that will allow them to catch up and thrive in a new system. This focus on current stability, no matter what the durable solution of the future, will allow children to be educated, the skills and knowledge of which are, ultimately, transferable between languages.

\section{Acknowledgements}

A version of this paper was presented at the African Studies Association Annual Meeting in New Orleans, November 2004. I would like to thank the Mellon Foundation, the Migration and Urbanisation Node of the University of the Witwatersrand, and the Fulbright Commission for their generous support of this research. Thank you also to Soo Hong and Priya Nalkur for insightful comments on an earlier draft of this paper and to Benjamin Piper for his assistance with literature on language of instruction in sub-Saharan Africa.

\section{References}

August, D. and K. Hakuta (Eds). 1998. Educating Language Minority Children. Committee on Developing a Research Agenda on the Education of Limited-English-Proficient and Bilingual Students, Commission on Behavioral and Social Sciences and Education, National Research Council, Institute of Medicine. Washington, D.C.: National Academy Press

Baker, V. 1996. Native language vs. national language literacy: choices and dilemmas in school instruction medium. Proceedings of the 1996 World Conference on literacy. Eckerd College: Florida.

Bamgbose, A. 1991. Language and the nation: the language question in sub-Saharan Africa. Edinburgh: Edinburgh University Press.

Banki, Susan. October 2004. "Refugee integration in the intermediate term: a study of Nepal, Pakistan, and Kenya." New Issues in Refugee Research, Working Paper No.108. Geneva: Evaluation and Policy Analysis Unit, UNHCR. 
Barongo, Yolamu Rufunda. "Problems of Integrating Banyarwanda Refugees among Local Communities in Uganda." In A.G.G. Gingyera Pinycwa (Ed). 1998. Uganda and the Problem of Refugees. Kampala: Makerere University Press.

Brock-Utne, Birgit and Halla B. Holmarsdottir. 2004. "Language policies and practices in Tanzania and South Africa: problems and challenges." International Journal of Educational Development 24: 67-83.

Crisp, Jeff. January 2003. "No solution in sight: the problem of protracted refugee situations in Africa." New Issues in Refugee Research, Working Paper No.75, Geneva: UNHCR.

Crisp, Jeff. 2004. "The local integration and local settlement of refugees: a conceptual and historical analysis." New Issues in Refugee Research, Working Paper No.102. Geneva: Evaluation and Policy Analysis Unit, UNHCR.

Dryden-Peterson, Sarah and Lucy Hovil. 2004. 'Local Integration of Refugees and Their Hosts in the Case of Uganda.' Refuge. 22(1): 26-28.

Dutcher, N. 2001. Expanding Educational Opportunity in Linguistically Diverse Societies. ERIC Document Reproduction Services No. ED 466099

Fanufwa, B.A. 1990. Using National Languages in Education: A Challenge to African Educators. In UNESCO. UNICEF (Eds). African Thoughts on the Prospects of Education for Alt. Selections from papers commissioned for the Regional Consultation on Education for All, Dakar, 27-30 November 1989, pp.97-110.

Inter-Agency Network for Education in Emergencies. 2004. Minimum Standards for Education in Emergencies, Chronic Crises and Early Reconstruction. Paris: UNESCO

Lawrence-Lightfoot, Sara and Jessica Davis. 1997. The Art and Science of Portraiture. San Francisco: Jossey-Bass.

National Curriculum Development Centre. 2000. Teacher's Guide to Uganda Primary School Curriculum, Volume One. Kampala: National Curriculum Development Centre.

National Curriculum Development Centre. 1999. Uganda Primary School Curriculum: Volume One. Kampala: National Curriculum Development Centre.

Office of the Prime Minister/UNHCR Uganda. 1999. "Strategy Paper: Self-Reliance for Refugee Hosting Areas in Moyo, Arua, and Adjumani Districts, 1999-2006."

Omoniyi, Tope. 2003. "Local Policies and Global Forces: Multiliteracy and Africa's Indigeneous Languages." Language Policy, 2:133-152.

Qorro, M. 2002. Language of Instruction Not Determinant in Quality Education. The Guardian. Wednesday 29 May 2002.

UNHCR. 2003a. Refugee Education Indicators. Geneva: UNHCR.

UNHCR. 2003b. Education Field Guidelines. Geneva: UNHCR.

UNHCR. 2004. Convention Plus: Issues Paper on Targeting of Development Assistance. Geneva: UNHCR.

UNHCR. 2005. Convention Plus at a Glance. Geneva: UNHCR.

USAID and ORC Macro. 2005. Demographic and Health Surveys. See www.measuredhs.com for more information.

\section{Interviews}

Bomera, George. 2003. Assistant Settlement Commandant, Kyaka II Refugee Settlement (25 March).

Bakunda, Félicien. 2004. Education Assistant, Uganda Red Cross Society, Kyaka II Refugee Settlement (1 July).

Please note that interviews with children, parents, and teachers are not cited in order to protect their identities.

\section{Notes}

All names of pupils, parents, and teachers have been changed to protect their identities.

2. This study of language of instruction at Bujubuli Primary School comes out of a larger research project on refugee education. In Uganda, the primary education of refugees takes place in three distinct arenas, which provided the sites for the three case studies that form this research: (1) UNHCR-sponsored primary schools in refugee settlements, attended primarily by refugees and some nationals; (2) government-funded primary schools in refugee settlements, attended primarily by nationals and some refugees; and (3) self-help schools in the major urban centre, Kampala, attended primarily by refugees and some nationals. Bujubuli Primary School is the case study representative of category two.

3 While kinship terms are especially problematic when it comes to translation, given cultural differences in conceptions and descriptions of kin relationships, the process of teaching students about the word 'cousin' was not unique but common to the teaching of vocabulary in general. 